\title{
Correction: Rating early child development outcome measurement tools for routine health programme use
}

Boggs D, Milner KM, Chandna J, et al. Rating early child development outcome measurement tools for routine health programme use. Arch Dis Child 2019;104:S22-33. doi:10.1136/archdischild-2018-315431.

The authors would like to correct the funding statement. Currently it reads as 'Funding: This supplement has been made possible by funding support from the Bernard van Leer Foundation. Saving Brains impact and process evaluation funded by Grand Challenges Canada.' This funding statement is correct for all the other papers in the series but for this specific paper a key funder (Children's Investment Fund Foundation) was not listed, and Grand Challenges Canada should not be listed.

The correct funding statement should be as follows: 'Funding: This supplement has been made possible by funding support from the Bernard van Leer Foundation (funding costs of publication and launch) and the Children's Investment Foundation Fund (partial funding of author time (DB) and (JC) and funding for EN-SMILING study).'

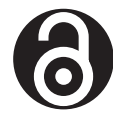

\section{OPEN ACCESS}

Open access This is an open access article distributed in accordance with the Creative Commons Attribution Non Commercial (CC BY-NC 4.0) license, which permits others to distribute, remix, adapt, build upon this work noncommercially, and license their derivative works on different terms, provided the original work is properly cited, appropriate credit is given, any changes made indicated, and the use is non-commercial. See: http://creativecommons.org/licenses/by-nc/ 4.0\%.

(C) Author(s) (or their employer(s)) 2020. Re-use permitted under CC BY-NC. No commercial re-use. See rights and permissions. Published by BMJ.

Arch Dis Child 2020;105:e3. doi:10.1136/archdischild-2018-315431corr1

A) Check for updates 